\title{
An epidemiological study of respiratory symptoms in Lancashire mills, 1963-66
}

\author{
M. K. B. MOLYNEUX ${ }^{1}$ and J. B. L. TOMBLESON \\ Department of Occupational Health, University of Manchester \\ and H.M. Medical Inspectorate of Factories
}

\begin{abstract}
Molyneux, M. K. B., and Tombleson, J. B. L. (1970). Brit. J. industr. Med., 27, 225-234. An epidemiological study of respiratory symptoms in Lancashire Mills, 1963-66. An epidemiological study of card and blowroom workers in 14 cotton spinning and two man-made fibre spinning mills in Lancashire has been carried out on a prospective basis of six-monthly examinations over three years. The number of operatives to be included was decided so as to give a sufficient sample for the statistical assessment of fall in FEV, at the same time allowing for population movement. The examination of each worker included a history, a questionnaire of respiratory symptoms, and a measurement of forced expiratory volume in one second. The results in this paper, which will be followed by others on other aspects of the survey, give the prevalence of both byssinosis and bronchitis, according to the definition given, in the 1359 cotton workers and 227 man-made fibre workers, seen at least once, and also the dust levels in the mills. Eight of the mills processed coarse and six medium cotton.

The total prevalence of byssinosis, as defined, is $26.9 \%$, being higher in coarse than in medium cotton mills, and the occupational groups most affected are strippers and grinders, carders and undercarders, and draw frame tenters. In coarse mills symptoms develop in some men and women within the first four years of exposure, and in medium mills between five and ten years' exposure. Repeat questionnaires in about half the population, two years after the first questionnaire, showed the development of symptoms of chest tightness in an appreciable number not previously affected. The incidence of bronchitis is increased in operatives with symptoms of byssinosis, but is influenced by age and smoking.

Total dust levels averaged $3.1 \mathrm{mg} / \mathrm{m}^{3}$ in coarse mills and $1.2 \mathrm{mg} / \mathrm{m}^{3}$ in medium mills. The findings indicate that dust control measures, though they have produced considerable improvement, are not now fully effective with present methods of production.
\end{abstract}

The results of previous population studies in the cotton spinning industry have shown that the occurrence of the symptom of chest tightness on Mondays depends upon occupation, length of exposure, and the quality of the raw cotton being processed. The symptom may be accompanied by detectable loss of ventilatory capacity and increased breathlessness (Prausnitz, 1936; Schilling, Hughes, DingwallFordyce, and Gilson, 1955; Bouhuys, Heaphy,

${ }^{1}$ Present address: Imperial Smelting Corporation (NSC) Ltd., St. Andrews Road, Avonmouth, Bristol, BS11 9HP.
Schilling, and Belborn, 1968) and the prevalence is highest in those occupations, i.e., carder, stripper, and grinder, in which serious disability has historically occurred (Home Office, 1932). Similarly, the symptom is present but the prevalence is low, in ring spinners in whom respiratory disability of occupational origin is rarely found. These facts support the view that Monday tightness is a specific symptom of byssinosis and that the appearance of the symptom itself may be followed in the susceptible individual by permanent disability. The diagnosis of 
the disease depends to a very great extent upon the voluntary admission that chest tightness occurs on the first day back at work after the weekend or longer period, and it is upon this fact that these population studies have been based. A questionnaire on respiratory symptoms (Medical Research Council, 1960), to which have been added questions concerning Monday tightness, has been used in the original and subsequent investigations of Schilling and others (Schilling et al., 1955; Roach and Schilling, 1960; Mekky, Roach, and Schilling, 1967). The prevalence and environmental data from one study (Roach and Schilling, 1960) form the basis of the recommended threshold limit value for cotton dust in cardrooms, i.e., $1 \mathrm{mg}$ total dust per $\mathrm{m}^{3}$ air.

The conclusions which arose from the work of Roach and Schilling (1960), together with those of McKerrow and his colleagues (McKerrow, McDermott, Gilson, and Schilling, 1958), form the basis of this prospective study, which had four main objectives. These were to investigate:

(a) the quantitative relationship between dust exposure and permanent respiratory impairment;

(b) the relationship between the change in pulmonary function during the day and permanent respiratory impairment;

(d) individual susceptibility and adaptation; and

(d) effectiveness of dust suppression equipment.

The concentrations of total dust and its respirable, medium and fly components have been measured by hexhlet and total samplers and the annual decline of forced expiratory volume $\left(\mathrm{FEV}_{\mathbf{1}}\right)$ has been used as the criterion of permanent respiratory impairment. The change in $\mathrm{FEV}_{1}$ has also been used to assess the change in ventilatory capacity during the first day back at work.

The small magnitude of the annual decline of $\mathrm{FEV}_{1}$ in cotton operatives, which is now known to be of the order of $50 \mathrm{ml}$ per year, required the survey to be planned prospectively over a period of three years. From 1963 to 1966 from one to six serial measurements of $\mathrm{FEV}_{1}$ were made on each of 1359 operatives employed in Lancashire cotton mills. Similar tests were made on 227 operatives working in similar occupations in two mills processing only man-made fibre. A record of respiratory symptoms was obtained for all operatives on their first interview, and the concentration of dust was determined in appropriate working areas of the cardroom. The respiratory symptoms of 669 of the operatives were recorded for a second time two years after their initial interview.

The purpose of this paper is to report upon the prevalence of respiratory symptoms and to discuss the effectiveness of dust suppression equipment. The inter-relationship of dust exposure, annual decline in $\mathrm{FEV}_{1}$, and the change in pulmonary function during the day will become the topics of subsequent more detailed publications. Our findings are particularly relevant following the installation of approved dust control hoods on cards (Ministry of Labour, 1957, 1960, 1961) and also following the observations of Wood and Roach (1964), which suggested that there is a continuing risk of respiratory disease in spinning processes.

\section{Population}

The operatives seen during the period 1963-66 worked in the blowing, carding, and associated processes of 16 Lancashire mills, of which eight processed coarse cotton, six processed medium cotton, and two processed manmade fibre.

The count of yarn spun in the medium mills ranged from 10 to 50 (60 to 12 Tex) and 1 to 24 (600 to $25 \mathrm{Tex}$ ) in the coarse mills. The trash (i.e., plant debris) content of the raw cotton ranged from 2 to $9 \%$ in medium mills and from 1 to $9 \%$ in coarse mills. Three mills incorporated man-made fibre into their product in proportions of $20 \%$, $25 \%$, and $16 \%$ respectively. The remaining 11 mills processed only raw cotton.

Out of a known total population of 1857 operatives aged 15 to 65 years, 1586 were interviewed. Of the 271 who were not interviewed, 151 were non-English speaking and the remainder were either absent from work or refused to attend (Table 1).

\section{TABLE 1}

Total Population aged 15-65 Years EMPLOYED IN BLOWING, CARDING, AND OTHER Processes

\begin{tabular}{lll|c|c}
\hline & & & Cotton & $\begin{array}{c}\text { Man-made } \\
\text { fibre }\end{array}$ \\
\hline Total seen. &. &. & 1359 & 227 \\
Non-English speaking &. &. & 138 & 13 \\
Absent or refused &. &. & 104 & 16 \\
Known total .0. &.. &. & 1601 & 256 \\
Percentage of total seen.. &. & 84.9 & $88 \cdot 7$ \\
& & & & \\
\hline
\end{tabular}

Of the total of 1359 cotton operatives, 1208 were interviewed during the first mill visit and the remainder on one or other of the subsequent visits. Table 2 shows the numbers of male and female operatives employed in the three types of mill.

TABLE 2

Numbers of Male and Female Operatives SEen in CotTon AND MAN-MAde Fibre Mills

\begin{tabular}{|c|c|c|c|c|c|}
\hline & & \multicolumn{3}{|c|}{ Cotton } & \multirow{2}{*}{$\begin{array}{c}\text { Man-made } \\
\text { fibre }\end{array}$} \\
\hline & & Medium & Coarse & Total & \\
\hline $\begin{array}{l}\text { Male } \\
\text { Female } .\end{array}$ & $\begin{array}{l}. \\
\ldots\end{array}$ & $\begin{array}{l}221 \\
312\end{array}$ & $\begin{array}{l}345 \\
481\end{array}$ & $\begin{array}{l}566 \\
793\end{array}$ & $\begin{array}{r}97 \\
130\end{array}$ \\
\hline Total .. & $\ldots$ & 533 & 826 & 1359 & 227 \\
\hline
\end{tabular}




\section{Method}

\section{Prevalence of respiratory symptoms}

The prevalences of byssinosis and bronchitis were determined by the use of a questionnaire on respiratory symptoms (Medical Research Council, 1960) to which were added questions on chest tightness (Roach and Schilling, 1960).

Byssinosis was classified as follows:

Grade $\frac{1}{2}$ Occasional chest tightness on Mondays

Grade I Chest tightness and/or difficulty in breathing on Mondays only

Grade II Chest tightness and/or difficulty in breathing on Mondays and other days.

Monday cough and irritation of the respiratory tract were not included as symptoms of byssinosis.

The prevalence of bronchitis is based upon the recommendations of the Medical Research Council (1966). Answers to questions 10, 12, and 21 of the questionnaire on respiratory symptoms were graded as follows:

Grade 1 Chronic phlegm (Q10) but no periodically increased phlegm (Q12) or chest illness (Q21)

Grade 2 Chronic phlegm (Q10) and increased phlegm on one occasion (Q12b) and/or chest illness on one occasion (Q21)

Grade 3 Chronic phlegm (Q10) and increased phlegm on more than one occasion (Q12c) and/or chest illness on more than one occasion (Q21).

The questionnaire was also used to provide information on age, present and previous occupation, length of exposure to cotton dust, and smoking habit. The term 'smoker' applies to all operatives who smoked one or more cigarettes per day regularly.

\section{Dust concentrations}

Hexhlet (Wright, 1954) and total samplers were used to measure the mass concentration of the respirable, medium, and fly components of the total dust. The fly fraction was deposited upon a $2 \times 2 \mathrm{~mm}$ gauze attached to the face of the total sampler and consisted mainly of cellulose fibre. The respirable fraction was collected on a 7-cm Whatman GFB disc of a hexhlet sampler and consisted of particles with a Stokes diameter of less than $7 \mu$. The medium fraction was collected in combination with the respirable fraction on the filter disc of the total sampler and its mass was determined indirectly. The particles of the medium fraction range from fibres of fly up to $2 \mathrm{~mm}$ in length to particles of cellulose fibre and plant debris of $7 \mu$ Stokes diameter. The hexhlet and total samplers operated at a rate of $501 / \mathrm{min}$ and $1001 / \mathrm{min}$ respectively. The method is similar to that used by Roach and Schilling (1960).

For the purposes of day to day sampling each cardroom was divided into working areas, corresponding to the areas normally occupied by operatives during working hours. Wherever possible the samplers and the operatives were located within similar environmental conditions and each sample was collected over a timed period of approximately six hours between $7.30 \mathrm{am}$ and $5.00 \mathrm{pm}$.

\section{Results}

Prevalence of byssinosis

The overall prevalence of byssinosis in cotton 2 operatives, shown in Table 3, was $26.7 \%$. The prevalence was slightly greater in men than in women and in both sexes grade 1 symptoms were the most common. Symptoms similar to those of byssinosis occurred in $10(4.4 \%)$ of the total population of the man-made fibre mills and all 10 had a previous history of exposure to cotton dust. Six of these operatives had been working in cotton mills within five years of the start of the investigation.

\section{TABLE 3}

Byssinosis: Prevalence (\%) in Population SEEN

\begin{tabular}{|c|c|c|c|c|c|c|}
\hline \multirow{2}{*}{ Grade } & \multicolumn{3}{|c|}{ All cotton } & \multicolumn{3}{|c|}{ Man-made fibre } \\
\hline & Male & Female & Total & Male & Female & Total \\
\hline$\frac{1}{2}$ & 6.9 & $6 \cdot 7$ & 6.8 & 1.0 & $2 \cdot 3$ & 1.8 \\
\hline I & $13 \cdot 8$ & $12 \cdot 7$ & $13 \cdot 2$ & $3 \cdot 1$ & 1.5 & $2 \cdot 2$ \\
\hline II & $7 \cdot 6$ & $6 \cdot 2$ & 6.8 & 0.0 & 0.8 & 0.4 \\
\hline Total & $28 \cdot 3$ & $25 \cdot 6$ & $26 \cdot 7$ & $4 \cdot 1$ & $4 \cdot 6$ & $4 \cdot 4$ \\
\hline No. & 566 & 793 & 1359 & 97 & 130 & 227 \\
\hline
\end{tabular}

Prevalence in 10 occupations The occupations of card tenting, drawframe tenting, and speedframe tenting were staffed almost entirely by female operatives, consequently the small numbers of male operatives employed in these occupations have been excluded from the analysis. Blow-room operatives, carders, undercarders, and strippers and grinders were all male. Table 4 shows the prevalence of byssinosis grades $\frac{1}{2}, \mathrm{I}$, and II in each occupation and the mean length of exposure, in years, to raw cotton. Seven of the 10 occupational groups were found both in coarse mills and in medium mills and, in all except blowroom operatives, the overall prevalence of byssinosis was greatest in operatives employed in coarse mills. Of the remaining occupations, comber tenters were found only in medium mills and ring spinners were seen only in coarse mills. The number of wastemen (2) seen in medium mills was too low to allow any comparison to be made. The three occupations of stripper and grinder, carder and undercarder, and drawframe tenter have the greatest prevalence of symptoms in both types of cotton mills. Grade II symptoms were present in all occupations except card tenters and labourers working in coarse mills and comber tenters in medium mills.

Prevalence in relation to age and duration of exposure The prevalence of byssinosis increases for a time with increasing age and duration of exposure (Tables 5a, b). There are only small differences in prevalence between the groups in the age range 30-59 years in the unadjusted data (Table 5a, col. 3) 
TABLE 4

Byssinosis: Prevalence (\%) in 10 Occupations in Medium and Coarse Mills

\begin{tabular}{|c|c|c|c|c|c|c|c|c|c|}
\hline \multirow{2}{*}{\multicolumn{3}{|c|}{ Occupation }} & \multirow{2}{*}{ Mill } & \multicolumn{4}{|c|}{ Prevalence (\%) } & \multirow{2}{*}{$\begin{array}{c}\text { Total } \\
\text { No. }\end{array}$} & \multirow{2}{*}{$\begin{array}{c}\text { Mean } \\
\text { exposure } \\
(y r)\end{array}$} \\
\hline & & & & Grade $\frac{1}{2}$ & Grade I & Grade II & All grades & & \\
\hline \multicolumn{3}{|c|}{ Blowroom and cotton chamber (male) } & $\begin{array}{l}\text { Medium } \\
\text { Coarse }\end{array}$ & $\begin{array}{l}6 \cdot 0 \\
6 \cdot 4\end{array}$ & $\begin{array}{r}12 \cdot 0 \\
4 \cdot 3\end{array}$ & $\begin{array}{l}6 \cdot 0 \\
3 \cdot 2\end{array}$ & $\begin{array}{l}24 \cdot 0 \\
13 \cdot 8\end{array}$ & $\begin{array}{l}50 \\
94\end{array}$ & $\begin{array}{r}9 \cdot 7 \\
11 \cdot 8\end{array}$ \\
\hline Carder, undercarder (male) & - & $\cdots$ & $\begin{array}{l}\text { Medium } \\
\text { Coarse }\end{array}$ & $\begin{array}{r}5 \cdot 3 \\
14 \cdot 5\end{array}$ & $\begin{array}{l}23 \cdot 7 \\
14 \cdot 5\end{array}$ & $\begin{array}{r}7.9 \\
10.9\end{array}$ & $\begin{array}{l}36 \cdot 8 \\
40 \cdot 0\end{array}$ & $\begin{array}{l}38 \\
55\end{array}$ & $\begin{array}{l}19 \cdot 1 \\
19 \cdot 2\end{array}$ \\
\hline Stripper and grinder (male) & $\cdots$ & $\cdots$ & $\begin{array}{l}\text { Medium } \\
\text { Coarse }\end{array}$ & $\begin{array}{l}9 \cdot 2 \\
9 \cdot 9\end{array}$ & $\begin{array}{l}22 \cdot 4 \\
34 \cdot 1\end{array}$ & $\begin{array}{l}17 \cdot 1 \\
14 \cdot 3\end{array}$ & $\begin{array}{l}48 \cdot 7 \\
58 \cdot 2\end{array}$ & $\begin{array}{l}76 \\
91\end{array}$ & $\begin{array}{l}18 \cdot 5 \\
17 \cdot 0\end{array}$ \\
\hline Card tenter (female) & $\cdots$ & $\cdots$ & $\begin{array}{l}\text { Medium } \\
\text { Coarse }\end{array}$ & $\begin{array}{l}0 \cdot 0 \\
8 \cdot 6\end{array}$ & $\begin{array}{r}7 \cdot 9 \\
17 \cdot 1\end{array}$ & $\begin{array}{l}2 \cdot 6 \\
0 \cdot 0\end{array}$ & $\begin{array}{l}10 \cdot 5 \\
25 \cdot 7\end{array}$ & $\begin{array}{l}38 \\
70\end{array}$ & $\begin{array}{r}13.9 \\
9 \cdot 6\end{array}$ \\
\hline Drawframe tenter (female) & . & $\cdots$ & $\begin{array}{l}\text { Medium } \\
\text { Coarse }\end{array}$ & $\begin{array}{r}7 \cdot 5 \\
11 \cdot 4\end{array}$ & $\begin{array}{r}9 \cdot 4 \\
14 \cdot 8\end{array}$ & $\begin{array}{l}13 \cdot 2 \\
14 \cdot 8\end{array}$ & $\begin{array}{l}30.2 \\
40.9\end{array}$ & $\begin{array}{l}53 \\
88\end{array}$ & $\begin{array}{l}20 \cdot 0 \\
22 \cdot 2\end{array}$ \\
\hline Speedframe tenter (female) & $\cdots$ & . & $\begin{array}{l}\text { Medium } \\
\text { Coarse }\end{array}$ & $\begin{array}{l}6 \cdot 0 \\
7 \cdot 6\end{array}$ & $\begin{array}{r}9 \cdot 0 \\
20 \cdot 5\end{array}$ & $\begin{array}{l}6 \cdot 0 \\
6 \cdot 7\end{array}$ & $\begin{array}{l}21 \cdot 0 \\
34 \cdot 8\end{array}$ & $\begin{array}{l}167 \\
210\end{array}$ & $\begin{array}{l}28 \cdot 0 \\
26 \cdot 8\end{array}$ \\
\hline Comber tenter (female) & $\cdots$ & $\cdots$ & $\begin{array}{l}\text { Medium } \\
\text { Coarse }\end{array}$ & $6 \cdot 0$ & $10 \cdot 0$ & $\frac{0.0}{-}$ & $\frac{16 \cdot 0}{-}$ & $\begin{array}{l}50 \\
(0)\end{array}$ & $\frac{14 \cdot 3}{-}$ \\
\hline Ring spinner (female) .. & $\cdots$ & $\cdots$ & $\begin{array}{l}\text { Medium } \\
\text { Coarse }\end{array}$ & $\overline{3 \cdot 7}$ & $\overline{3 \cdot 7}$ & $\overrightarrow{3 \cdot 7}$ & $\overrightarrow{11 \cdot 1}$ & $\begin{array}{c}(0) \\
108\end{array}$ & $\overline{18.0}$ \\
\hline Labourer (male) & $\cdots$ & $\cdots$ & $\begin{array}{l}\text { Medium } \\
\text { Coarse }\end{array}$ & $\begin{array}{l}0 \cdot 0 \\
4 \cdot 8\end{array}$ & $\begin{array}{l}0 \cdot 0 \\
0 \cdot 0\end{array}$ & $\begin{array}{l}4 \cdot 0 \\
0.0\end{array}$ & $\begin{array}{l}4 \cdot 0 \\
4 \cdot 8\end{array}$ & $\begin{array}{l}25 \\
42\end{array}$ & $\begin{array}{l}8 \cdot 3 \\
6 \cdot 8\end{array}$ \\
\hline Wasteman (male) & $\cdots$ & $\cdots$ & $\begin{array}{l}\text { Medium } \\
\text { Coarse }\end{array}$ & $\overline{15 \cdot 4}$ & $\overrightarrow{0.0}$ & $\overline{7 \cdot 7}$ & $\overline{23 \cdot 1}$ & $\begin{array}{l}(2) \\
13\end{array}$ & $\overline{14 \cdot 5}$ \\
\hline
\end{tabular}

but, after adjustment for exposure, there is a steady decline in prevalence from the age of 30 years onwards (Table 5a, col. 4). The effects of age and exposure were separated by fitting additive age and exposure efforts to the logit transformation of byssinosis prevalence (Berry, 1970) and adjustment

TABLE 5a

Byssinosis: Prevalence (\%) in 10 Age Groups

\begin{tabular}{c|c|c|c|c}
\hline $\begin{array}{c}(1) \\
\text { Age }(y r)\end{array}$ & $\begin{array}{c}(2) \\
\text { No. in } \\
\text { group }\end{array}$ & $\begin{array}{c}(3) \\
\text { Observed } \\
\text { prevalence }\end{array}$ & $\begin{array}{c}(4) \\
\text { Prevalence } \\
\text { adjusted } \\
\text { for } \\
\text { exposure }\end{array}$ & $\begin{array}{c}(5) \\
\text { Prevalence } \\
\text { adjusted for } \\
\text { exposure, } \\
\text { milltype, and } \\
\text { sex }\end{array}$ \\
\hline $15-19$ & 149 & $2 \cdot 0$ & $7 \cdot 3$ & $7 \cdot 4$ \\
$20-24$ & 91 & $7 \cdot 7$ & $16 \cdot 5$ & $16 \cdot 6$ \\
$25-29$ & 88 & $23 \cdot 9$ & $31 \cdot 2$ & $31 \cdot 8$ \\
$30-34$ & 133 & $31 \cdot 6$ & $35 \cdot 0$ & $36 \cdot 1$ \\
$35-39$ & 147 & $36 \cdot 1$ & $34 \cdot 0$ & $35 \cdot 5$ \\
$40-44$ & 144 & $34 \cdot 0$ & $31 \cdot 0$ & $31 \cdot 2$ \\
$45-49$ & 142 & $35 \cdot 2$ & $29 \cdot 8$ & $30 \cdot 5$ \\
$50-54$ & 190 & $30 \cdot 5$ & $23 \cdot 8$ & $23 \cdot 9$ \\
$55-59$ & 185 & $32 \cdot 4$ & $24 \cdot 3$ & $23 \cdot 4$ \\
$60+$ & 90 & $22 \cdot 2$ & $17 \cdot 6$ & $15 \cdot 6$ \\
\hline
\end{tabular}

was also made for the type of cotton processed and sex by including mill type/sex constants in the above method. Adjusted prevalences were then calculated by applying the direct method of standardization to the expected prevalences. This approach gave a satisfactory fit to the data except for women with

TABLE $5 b$

Byssinosis: Prevalence (\%) in Nine Exposure GrouPs

\begin{tabular}{c|c|c|c|c}
\hline $\begin{array}{c}(I) \\
\begin{array}{c}\text { Exposure } \\
(y r)\end{array}\end{array}$ & $\begin{array}{c}(2) \\
\text { No. in } \\
\text { group }\end{array}$ & $\begin{array}{c}(3) \\
\text { Observed } \\
\text { prevalence }\end{array}$ & $\begin{array}{c}(4) \\
\text { Prevalence } \\
\text { adjusted } \\
\text { for age }\end{array}$ & $\begin{array}{c}(5) \\
\text { Prevalence } \\
\text { adjusted for } \\
\text { age, milltype, } \\
\text { and sex }\end{array}$ \\
\hline $0-4$ & 305 & $5 \cdot 2$ & $8 \cdot 8$ & $8 \cdot 0$ \\
$5-9$ & 155 & $23 \cdot 3$ & $20 \cdot 5$ & $19 \cdot 2$ \\
$10-14$ & 168 & $28 \cdot 0$ & $22 \cdot 3$ & $21 \cdot 0$ \\
$15-19$ & 187 & $35 \cdot 8$ & $29 \cdot 5$ & $27 \cdot 5$ \\
$20-24$ & 117 & $36 \cdot 8$ & $30 \cdot 9$ & $31 \cdot 1$ \\
$25-29$ & 115 & $43 \cdot 5$ & $40 \cdot 2$ & $42 \cdot 4$ \\
$30-34$ & 94 & $30 \cdot 9$ & $30 \cdot 2$ & $35 \cdot 1$ \\
$35-39$ & 99 & $35 \cdot 4$ & $36 \cdot 5$ & $41 \cdot 4$ \\
$40+$ & 119 & $33 \cdot 6$ & $37 \cdot 7$ & $41 \cdot 8$ \\
\hline
\end{tabular}


less than five years' exposure to coarse cotton for whom there was an excess of byssinotics aged less than 30 years ( 9 observed compared with 2 expected). This part of the data does not fit in with the overall pattern of results.

After adjustment for age alone there is no appreciable decrease in prevalence as the duration of exposure increases (Table $5 \mathrm{~b}, \mathrm{col} .4$ ), and the slight decrease that is seen is due to imbalance between sex and exposure. Approximately half of the subjects with less than 20 years' exposure are males, but for more than 20 years' exposure the proportion is about a quarter, and after adjustment for age, mill type, and sex (Table 5b, col. 5), there is no evidence of a fall in prevalence in the groups exposed for more than 25 years. The result of adjustment for exposure, mill type, and sex in the 10 age groups is very similar to the exposure adjusted data (Table 5a, cols. 4 and 5).

Occupational risk in approved conditions The overall prevalence of disease in the occupations shown in Table 4 is based upon groups whose average lengths of exposure to raw cotton vary from 6.8 to 28.0 years. As such these data give no real indication of the risk of developing the disease since the installation of the approved dust control systems (Ministry of Labour, 1957, 1960, 1961) which were fitted to the cards in 12 of the 14 card-rooms. Some measure of risk can be obtained by comparing the prevalence of byssinosis in groups of operatives exposed for periods of 4,9 , and 14 years prior to the survey. This is shown in Tables $6 \mathrm{a}$ and $\mathrm{b}$. In coarse mills symptoms of byssinosis were present in six occupations after exposure of up to four years ranging from $2.7 \%$ in blowroom operatives to $20.0 \%$ in drawframe operatives. No symptoms were found in carders and undercarders or strippers and grinders with exposure of up to four years, but the number in both groups is small. By comparison, in medium mills, only one man, a stripper and grinder, had symptoms of byssinosis after exposure of four years to cotton.

A comparison of the symptoms in the 669 operatives who were re-interviewed after two years provides evidence of the development of new cases

TABLE 6a

Byssinosis: Prevalence ( $\%$ ) in 10 Occupations in Coarse Mills after Exposure of 4,9 and 14 Years to Cotton

\begin{tabular}{|c|c|c|c|c|c|c|c|c|c|}
\hline \multirow{3}{*}{ Occupation } & & & & \multicolumn{6}{|c|}{ Exposure } \\
\hline & & & & \multicolumn{2}{|c|}{$0-4$ years } & \multicolumn{2}{|c|}{$5-9$ years } & \multicolumn{2}{|c|}{ 10-14 years } \\
\hline & & & & No. & Prevalence & No. & Prevalence & No. & Prevalence \\
\hline $\begin{array}{l}\text { Blowroom operative (male) } \\
\text { Carder, undercarder (male) } \\
\text { Stripper and grinder (male) } \\
\text { Card tenter (female) } \\
\text { Drawframe tenter (female) } \\
\text { Speedframe tenter (female) } \\
\text { Ringspinner (female) .. } \\
\text { Labourer (male) } \quad \text {. }\end{array}$ & $\begin{array}{l}\cdots \\
\cdots \\
\cdots \\
\cdots \\
\cdots \\
\cdots \\
\cdots \\
\cdots\end{array}$ & $\begin{array}{l}\cdots \\
\cdots \\
\cdots \\
\cdots \\
\cdots \\
\cdots \\
\cdots\end{array}$ & $\begin{array}{l}\cdots \\
\cdots \\
\cdots \\
\cdots \\
\cdots \\
\cdots \\
\cdots \\
\cdots\end{array}$ & $\begin{array}{r}37 \\
7 \\
5 \\
32 \\
5 \\
18 \\
25 \\
28\end{array}$ & $\begin{array}{l}2 \cdot 7 \\
0 \\
0 \\
18 \cdot 8 \\
20 \cdot 0 \\
16 \cdot 7 \\
4 \cdot 0 \\
3 \cdot 6\end{array}$ & $\begin{array}{r}14 \\
8 \\
19 \\
10 \\
8 \\
11 \\
17 \\
6\end{array}$ & $\begin{array}{l}14 \cdot 3 \\
37 \cdot 5 \\
36 \cdot 8 \\
20 \cdot 0 \\
62 \cdot 5 \\
18 \cdot 2 \\
0 \\
0\end{array}$ & $\begin{array}{r}11 \\
5 \\
22 \\
11 \\
14 \\
11 \\
14 \\
3\end{array}$ & $\begin{array}{c}36 \cdot 4 \\
0 \\
59 \cdot 1 \\
27 \cdot 3 \\
21 \cdot 4 \\
27 \cdot 3 \\
14 \cdot 3 \\
0\end{array}$ \\
\hline
\end{tabular}

TABLE $6 \mathrm{~b}$

Byssinosis: Prevalence ( $\%$ ) in 10 Occupations in Medium Mills after Exposure OF 4, 9 , AND 14 YeARS to CotTON

\begin{tabular}{|c|c|c|c|c|c|c|c|c|c|}
\hline \multirow{3}{*}{\multicolumn{2}{|c|}{ Occupation }} & & & \multicolumn{6}{|c|}{ Exposure } \\
\hline & & & & \multicolumn{2}{|c|}{$0-4$ years } & \multicolumn{2}{|c|}{$5-9$ years } & \multicolumn{2}{|c|}{$10-14$ years } \\
\hline & & & & $\begin{array}{c}\text { No. in } \\
\text { in group }\end{array}$ & Prevalence & $\begin{array}{c}\text { No. } \\
\text { in group }\end{array}$ & Prevalence & $\begin{array}{c}\text { No. } \\
\text { in group }\end{array}$ & Prevalence \\
\hline $\begin{array}{l}\text { Blowroom operative (male) } \\
\text { Carder, undercarder (male) } \\
\text { Stripper and grinder (male) } \\
\text { Carder tenter (female) } \\
\text { Drawframe tenter (female) } \\
\text { Speedframe tenter (female) } \\
\text { Comber tenter (female) } \\
\text { Labourer (male) }\end{array}$ & $\begin{array}{l}\cdots \\
\cdots \\
\cdots \\
\cdots \\
\cdots \\
\cdots \\
\cdots\end{array}$ & $\begin{array}{l}\cdots \\
\cdots \\
\cdots \\
\cdots \\
\cdots \\
\cdots \\
\cdots\end{array}$ & $\begin{array}{l}\cdots \\
\cdots \\
\cdots \\
\cdots \\
\cdots \\
\cdots \\
\cdots\end{array}$ & $\begin{array}{r}20 \\
7 \\
4 \\
15 \\
5 \\
7 \\
15 \\
12\end{array}$ & $\begin{array}{r}0 \\
0 \\
25 \\
0 \\
0 \\
0 \\
0 \\
0\end{array}$ & $\begin{array}{r}7 \\
3 \\
9 \\
4 \\
10 \\
6 \\
7 \\
7\end{array}$ & $\begin{array}{c}57 \cdot 1 \\
0 \\
44 \cdot 4 \\
10 \cdot 0 \\
10 \cdot 0 \\
0 \\
28 \cdot 6 \\
14 \cdot 3\end{array}$ & $\begin{array}{r}7 \\
5 \\
18 \\
4 \\
5 \\
16 \\
8 \\
2\end{array}$ & $\begin{array}{c}28.6 \\
60.0 \\
33.3 \\
0 \\
40.0 \\
12.5 \\
50.0 \\
0\end{array}$ \\
\hline
\end{tabular}


of byssinosis. Table 7 shows that, while in medium mills the prevalence of byssinosis is similar on the two occasions, in coarse mills there is a marked increase in prevalence.

In medium mills, of 184 operatives who had no symptoms on the first visit, $\mathbf{9 \cdot 2} \%$ developed symptoms by the repeat visit. By comparison, in coarse mills, $25.4 \%$ ( 76 out of 299 ) developed symptoms during the same period of time. Table 7 also shows that some operatives who reported symptoms on the first visit failed to report them on the repeat visit. In medium mills this occurred in $30.0 \%$ of byssinotics (18 out of 60 ) and in coarse mills in $26.9 \%$ (34 out of
126). The same observers used the same questionnaire on both occasions at approximately the same time of year.

\section{Prevalence of bronchitis}

The prevalence of grades 1,2 , and 3 bronchitis is compared for both sexes in cotton and man-made fibre and for smoking habit and byssinosis in Tables $8(a, b)$ and $9(a, b)$. In cotton mills bronchitis of all grades is more prevalent in smokers than in non-smokers, and this is most noticeable in men with grade 1 bronchitis. In the comparison of cotton and man-made fibre operatives the greatest difference is

TABLE 7

Byssinosis: A COMPARISON OF THE INITIAL AND REPEAT QUESTIONNAIRES

\begin{tabular}{|c|c|c|c|c|c|c|c|c|c|c|c|}
\hline \multirow{3}{*}{$\begin{array}{l}\text { Byssinosis grade } \\
\text { First questionnaire }\end{array}$} & \multicolumn{5}{|c|}{ Medium mills } & \multicolumn{5}{|c|}{ Coarse mills } & \multirow{3}{*}{ Total } \\
\hline & \multicolumn{5}{|c|}{$\begin{array}{c}\text { Byssinosis grade } \\
\text { Second questionnaire }\end{array}$} & \multicolumn{5}{|c|}{$\begin{array}{c}\text { Byssinosis grade } \\
\text { Second questionnaire }\end{array}$} & \\
\hline & Total & 0 & $\frac{1}{2}$ & $I$ & II & Total & 0 & $\frac{1}{2}$ & $I$ & II & \\
\hline $\begin{array}{l}0 \\
\frac{1}{2} \\
\text { I } \\
\text { II }\end{array}$ & $\begin{array}{r}184 \\
14 \\
28 \\
18\end{array}$ & $\begin{array}{r}167 \\
4 \\
10 \\
4\end{array}$ & $\begin{array}{l}3 \\
2 \\
3 \\
4\end{array}$ & $\begin{array}{l}8 \\
6 \\
9 \\
1\end{array}$ & $\begin{array}{l}6 \\
2 \\
6 \\
9\end{array}$ & $\begin{array}{r}299 \\
33 \\
65 \\
28\end{array}$ & $\begin{array}{r}223 \\
11 \\
17 \\
6\end{array}$ & $\begin{array}{r}24 \\
10 \\
7 \\
2\end{array}$ & $\begin{array}{r}36 \\
9 \\
22 \\
10\end{array}$ & $\begin{array}{r}16 \\
3 \\
19 \\
10\end{array}$ & \\
\hline Total & 244 & 185 & 12 & 24 & 23 & 425 & 257 & 43 & 77 & 48 & 669 \\
\hline
\end{tabular}

TABLE 8

Bronchitis: Prevalence in Cotton and Man-made Fibre Operatives

(a) Observed prevalence (\%)

\begin{tabular}{|c|c|c|c|c|c|c|c|c|c|}
\hline \multirow{3}{*}{ Sex } & & & & \multicolumn{6}{|c|}{ Grade of bronchitis } \\
\hline & & \multicolumn{2}{|c|}{ No. } & \multicolumn{2}{|c|}{1} & \multicolumn{2}{|c|}{2} & \multicolumn{2}{|c|}{3} \\
\hline & & $S$ & $N S$ & $S$ & $N S$ & $S$ & $N S$ & $S$ & $N S$ \\
\hline $\mathbf{M}$ & $\begin{array}{l}\text { Cotton } \\
\text { MMF }\end{array}$ & $\begin{array}{r}428 \\
77\end{array}$ & $\begin{array}{r}138 \\
20\end{array}$ & $\begin{array}{l}31 \cdot 1 \\
22 \cdot 1\end{array}$ & $\begin{array}{l}17 \cdot 4 \\
15 \cdot 0\end{array}$ & $\begin{array}{l}9 \cdot 1 \\
3 \cdot 9\end{array}$ & $\begin{array}{l}6 \cdot 5 \\
5 \cdot 0\end{array}$ & $\begin{array}{l}7 \cdot 5 \\
2 \cdot 6\end{array}$ & $\begin{array}{l}5 \cdot 1 \\
0.0\end{array}$ \\
\hline $\mathbf{F}$ & $\begin{array}{l}\text { Cotton } \\
\text { MMF }\end{array}$ & $\begin{array}{r}447 \\
62\end{array}$ & $\begin{array}{r}346 \\
68\end{array}$ & $\begin{array}{l}17 \cdot 2 \\
11 \cdot 3\end{array}$ & $\begin{array}{l}12 \cdot 1 \\
16 \cdot 2\end{array}$ & $\begin{array}{l}8 \cdot 5 \\
4 \cdot 8\end{array}$ & $\begin{array}{l}6.6 \\
5.9\end{array}$ & $\begin{array}{l}9.4 \\
1.6\end{array}$ & $\begin{array}{l}3 \cdot 5 \\
4 \cdot 4\end{array}$ \\
\hline
\end{tabular}

(b) Age-adjusted prevalence (\%)

\begin{tabular}{|c|c|c|c|c|c|c|c|c|c|}
\hline $\mathbf{M}$ & $\begin{array}{l}\text { Cotton } \\
\text { MMF }\end{array}$ & $\begin{array}{r}428 \\
77\end{array}$ & $\begin{array}{r}138 \\
20\end{array}$ & $\begin{array}{l}31 \cdot 8 \\
23.6\end{array}$ & $\begin{array}{l}17 \cdot 8 \\
17 \cdot 7\end{array}$ & $\begin{array}{l}9 \cdot 4 \\
3.9\end{array}$ & $\begin{array}{l}7 \cdot 1 \\
6 \cdot 2\end{array}$ & $\begin{array}{l}7 \cdot 8 \\
2 \cdot 6\end{array}$ & $\begin{array}{l}5.4 \\
0.0\end{array}$ \\
\hline $\mathbf{F}$ & $\begin{array}{l}\text { Cotton } \\
\text { MMF }\end{array}$ & $\begin{array}{r}447 \\
62\end{array}$ & $\begin{array}{r}346 \\
68\end{array}$ & $\begin{array}{l}17 \cdot 1 \\
11 \cdot 4\end{array}$ & $\begin{array}{l}11 \cdot 5 \\
15 \cdot 7\end{array}$ & $\begin{array}{l}8.9 \\
5 \cdot 1\end{array}$ & $\begin{array}{l}5.8 \\
5 \cdot 7\end{array}$ & $\begin{array}{l}9.9 \\
1.8\end{array}$ & $\begin{array}{l}3 \cdot 0 \\
4 \cdot 0\end{array}$ \\
\hline
\end{tabular}

$\mathbf{S}=$ Smoker

NS $=$ Non-smoker

MMF = Man-made fibre 
TABLE 9

Bronchitis: Relationship with Byssinosis and SMoking Habit in Cotton Operatives

(a) Observed prevalence (\%)

\begin{tabular}{|c|c|c|c|c|c|c|c|c|c|}
\hline \multirow{3}{*}{ Sex } & & & & \multicolumn{6}{|c|}{ Grade of bronchitis } \\
\hline & & \multicolumn{2}{|c|}{ No. } & \multicolumn{2}{|c|}{1} & \multicolumn{2}{|c|}{2} & \multicolumn{2}{|c|}{3} \\
\hline & & $S$ & $N S$ & $S$ & $N S$ & $S$ & $N S$ & $S$ & $N S$ \\
\hline $\mathbf{M}$ & $\begin{array}{l}\text { No byssinosis } \\
\text { Byssinosis }\end{array}$ & $\begin{array}{l}301 \\
127\end{array}$ & $\begin{array}{r}105 \\
33\end{array}$ & $\begin{array}{l}30 \cdot 2 \\
33 \cdot 1\end{array}$ & $\begin{array}{r}7.6 \\
48.5\end{array}$ & $\begin{array}{r}6.6 \\
15.0\end{array}$ & $\begin{array}{l}8.6 \\
0.0\end{array}$ & $\begin{array}{r}5 \cdot 3 \\
12 \cdot 6\end{array}$ & $\begin{array}{r}2 \cdot 9 \\
12 \cdot 1\end{array}$ \\
\hline $\mathbf{F}$ & $\begin{array}{l}\text { No byssinosis } \\
\text { Byssinosis }\end{array}$ & $\begin{array}{l}322 \\
125\end{array}$ & $\begin{array}{r}268 \\
78\end{array}$ & $\begin{array}{l}14 \cdot 3 \\
24 \cdot 8\end{array}$ & $\begin{array}{l}10.4 \\
17.9\end{array}$ & $\begin{array}{l}8.7 \\
8.0\end{array}$ & $\begin{array}{r}5 \cdot 6 \\
10 \cdot 3\end{array}$ & $\begin{array}{r}6 \cdot 2 \\
17 \cdot 6\end{array}$ & $\begin{array}{r}1 \cdot 5 \\
10 \cdot 3\end{array}$ \\
\hline
\end{tabular}

(b) Age-adjusted prevalence (\%)

\begin{tabular}{|c|c|c|c|c|c|c|c|c|c|}
\hline $\mathbf{M}$ & $\begin{array}{l}\text { No byssinosis } \\
\text { Byssinosis }\end{array}$ & $\begin{array}{l}301 \\
127\end{array}$ & $\begin{array}{r}105 \\
33\end{array}$ & $\begin{array}{l}32.5 \\
30 \cdot 2\end{array}$ & $\begin{array}{r}8 \cdot 1 \\
43 \cdot 8\end{array}$ & $\begin{array}{r}7 \cdot 3 \\
13 \cdot 7\end{array}$ & $\begin{array}{l}9.9 \\
0.0\end{array}$ & $\begin{array}{r}5.9 \\
11.5\end{array}$ & $\begin{array}{r}3 \cdot 2 \\
10 \cdot 7\end{array}$ \\
\hline $\mathbf{F}$ & $\begin{array}{l}\text { No byssinosis } \\
\text { Byssinosis }\end{array}$ & $\begin{array}{l}322 \\
125\end{array}$ & $\begin{array}{r}268 \\
78\end{array}$ & $\begin{array}{l}14 \cdot 6 \\
22 \cdot 9\end{array}$ & $\begin{array}{l}10 \cdot 1 \\
16.9\end{array}$ & $\begin{array}{l}9 \cdot 3 \\
8 \cdot 0\end{array}$ & $\begin{array}{l}5.0 \\
8.4\end{array}$ & $\begin{array}{r}6 \cdot 8 \\
16.9\end{array}$ & $\begin{array}{l}1 \cdot 3 \\
8 \cdot 3\end{array}$ \\
\hline
\end{tabular}

$\mathbf{S}=$ Smoker $\quad$ NS $=$ Non-smoker

found between groups of smokers. Smokers of both sexes who work in cotton have a consistently greater prevalence of bronchitis of all three grades. A comparison of byssinotics and non-byssinotics (Table 9a, b) shows that bronchitis grades 1 and 3 are more prevalent in byssinotics irrespective of smoking habit. In the case of male non-smokers with grade 2 bronchitis the effect is reversed. With the exception of this group, non-smokers who have no symptoms of byssinosis have the lowest prevalence of bronchitis. In male non-smokers there is an increase in grade 1 bronchitis with increasing age up to 54 years (Table 10). This is not apparent in all three grades but, because of possible age dependence, Tables 8 and 9 also show the age-adjusted prevalence. The interpretation of the results is similar in both cases.

\section{Concentration of dust in cotton mills}

The average concentration of total dust in coarse mills in the areas of the cards, drawframes, and speedframes was $3.1 \mathrm{mg} / \mathrm{m}^{3}$ compared with 1.2 $\mathrm{mg} / \mathrm{m}^{3}$ in medium mills. The concentration of each dust fraction, with one exception, was also greater in coarse mills.

Thirteen cardrooms had average total dust levels

TABLE 10

Bronchitis: Relationship between Age and Prevalence (\%) of Bronchitis in Non-smokers Working in Cotton and Man-Made Fibre

\begin{tabular}{|c|c|c|c|c|c|c|c|c|c|c|c|c|c|}
\hline & & & & \multicolumn{5}{|c|}{ Cotton } & \multicolumn{5}{|c|}{ Man-made fibre } \\
\hline \multicolumn{4}{|c|}{ Age (years) } & $15-24$ & $25-34$ & $35-44$ & $45-54$ & $55+$ & $15-24$ & $25-34$ & $35-44$ & $45-54$ & $55+$ \\
\hline $\begin{array}{l}\text { Male } \\
\text { Grade 1 } \\
\text { Grade 2 } \\
\text { Grade 3 } \\
\text { (No.) }\end{array}$ & $\begin{array}{l}\ddot{.} \\
\ddot{*} \\
\cdots\end{array}$ & $\begin{array}{l}\cdots \\
\cdots \\
\cdots \\
\cdots\end{array}$ & $\begin{array}{l}\cdots \\
\cdots \\
\cdots\end{array}$ & $\begin{array}{c}5 \cdot 6 \\
8 \cdot 3 \\
0 \\
(36)\end{array}$ & $\begin{array}{c}20 \cdot 0 \\
0 \\
4 \cdot 0 \\
(25)\end{array}$ & $\begin{array}{c}25 \cdot 0 \\
3 \cdot 1 \\
0 \\
(32)\end{array}$ & $\begin{array}{c}28 \cdot 6 \\
14 \cdot 3 \\
0 \\
(21)\end{array}$ & $\begin{array}{r}12 \cdot 5 \\
8 \cdot 3 \\
25 \cdot 0 \\
(24)\end{array}$ & $\begin{array}{c}0 \\
0 \\
0 \\
(9)\end{array}$ & $\begin{array}{l}\bar{Z} \\
\overline{(0)}\end{array}$ & $\begin{array}{c}0 \\
0 \\
0 \\
(3)\end{array}$ & $\begin{array}{c}42 \cdot 9 \\
14 \cdot 3 \\
0 \\
(7)\end{array}$ & $\begin{array}{l}0 \\
0 \\
0 \\
(1)\end{array}$ \\
\hline $\begin{array}{l}\text { Female } \\
\text { Grade 1 } \\
\text { Grade 2 } \\
\text { Grade 3 } \\
\text { (No.) }\end{array}$ & $\begin{array}{l}. \\
\cdots \\
\cdots \\
.\end{array}$ & $\begin{array}{l}\ddot{ } \\
\ddot{.} \\
\cdots\end{array}$ & $\begin{array}{l}\ldots \\
\cdots \\
\cdots\end{array}$ & $\begin{array}{l}0 \\
0 \\
0 \\
(25)\end{array}$ & $\begin{array}{c}5 \cdot 4 \\
16 \cdot 2 \\
0 \\
(37)\end{array}$ & $\begin{array}{r}11 \cdot 5 \\
3.8 \\
1.9 \\
(52)\end{array}$ & $\begin{array}{r}17 \cdot 6 \\
5.9 \\
5 \cdot 9 \\
(119)\end{array}$ & $\begin{array}{r}11.5 \\
7.0 \\
3.5 \\
(113)\end{array}$ & $\begin{array}{c}11 \cdot 1 \\
0 \\
0 \\
(9)\end{array}$ & $\begin{array}{c}20 \cdot 0 \\
0 \\
0 \\
(5)\end{array}$ & $\begin{array}{c}15 \cdot 8 \\
5 \cdot 3 \\
0 \\
(19)\end{array}$ & $\begin{array}{c}17 \cdot 7 \\
11 \cdot 8 \\
0 \\
(17)\end{array}$ & $\begin{array}{r}16 \cdot 7 \\
5.6 \\
16 \cdot 7 \\
(18)\end{array}$ \\
\hline
\end{tabular}


in excess of $1.0 \mathrm{mg} / \mathrm{m}^{3}$ (Table 11) with the majority of samples falling within the range 0.5 to $3.0 \mathrm{mg} / \mathrm{m}^{3}$ in individual processes. The greatest total dust concentrations occurred in the speedframe areas exceeding $5.0 \mathrm{mg} / \mathrm{m}^{3}$ in two mills. The total dust consisted of approximately equal proportions of the respirable and medium fractions ranging from 15 to $32 \%$ and 10 to $30 \%$ of the total concentration respectively. A comparison of the average concentration of total dust and its fractions in five cardroom processes (Table 12) shows that in medium mills dust level decreases as the distance from the cards increases, but in coarse mills cards and drawframes produced less dust than speedframes, which were mostly of the newer, high speed type. The cards produced less fly and more respirable and medium dust than four of the subsequent processes, but in coarse mills the speedframes produced comparable levels of the respirable fraction.

\section{Discussion}

A number of previous reports and investigations give some indication of progress towards the control of respiratory disease in Lancashire cotton operatives. The fitting of the first approved dust control systems to carding engines resulted in a substantial decrease in total dust concentration and also a

\section{TABLE 11}

Average Dust Concentrations $\left(\mathrm{mg} / \mathrm{m}^{3}\right)$ IN THE CARdrooms of 14 CotTon Mills

\begin{tabular}{r|cccc|c}
\hline & Respirable & Medium & Fly & Total & $\begin{array}{c}\text { No. of } \\
\text { samples }\end{array}$ \\
\hline $\begin{array}{c}\text { All mills } \\
\text { Medium } \\
\text { mills }\end{array}$ & $0.48(21)^{1}$ & $0.49(21)$ & $1.28(58)$ & 2.26 & 562 \\
Coarse & & & & & \\
mills & $0.25(23)$ & $0.31(26)$ & $0.60(51)$ & 1.18 & 245 \\
\hline Medium & & & & & \\
Mill 1 & 0.19 & 0.26 & 0.55 & 1.00 & 47 \\
2 & 0.24 & 0.42 & 0.93 & 1.59 & 34 \\
3 & 0.32 & 0.36 & 0.56 & 1.24 & 28 \\
4 & 0.22 & 0.24 & 0.62 & 1.08 & 68 \\
5 & 0.35 & 0.38 & 0.52 & 1.25 & 36 \\
6 & 0.30 & 0.21 & 0.43 & 0.94 & 32 \\
Coarse & & & & & \\
Mill 7 & 0.42 & 0.53 & 0.92 & 1.87 & 37 \\
8 & 0.39 & 0.49 & 1.13 & 2.01 & 55 \\
9 & 0.63 & 0.26 & 1.60 & 2.49 & 19 \\
10 & 0.61 & 0.72 & 2.72 & 4.05 & 65 \\
11 & 0.60 & 0.68 & 1.93 & 3.21 & 45 \\
12 & 0.94 & 1.16 & 3.23 & 5.33 & 36 \\
13 & 0.91 & 0.68 & 1.51 & 3.10 & 35 \\
14 & 0.63 & 0.49 & 1.30 & 2.42 & 25 \\
\hline & & & & & \\
\hline
\end{tabular}

${ }^{1}$ Percentage of total concentration.
TABLE 12

Average Dust Concentrations $\left(\mathrm{mg} / \mathrm{m}^{3}\right.$ ) in Five Cardroom Processes

\begin{tabular}{|c|c|c|c|c|c|}
\hline Process & Mill & Respirable & Medium & Fly & Total \\
\hline Cards & $\begin{array}{l}\text { Medium } \\
\text { Coarse } \\
\text { Total }\end{array}$ & $\begin{array}{l}0.37 \\
0.36 \\
0.65\end{array}$ & $\begin{array}{l}0.43 \\
0.64 \\
0.55\end{array}$ & $\begin{array}{l}0.56 \\
1.37 \\
1.02\end{array}$ & $\begin{array}{l}1 \cdot 36 \\
2 \cdot 87 \\
2 \cdot 22\end{array}$ \\
\hline Drawframes & $\begin{array}{l}\text { Medium } \\
\text { Coarse } \\
\text { Total }\end{array}$ & $\begin{array}{l}0.23 \\
0.56 \\
0.42\end{array}$ & $\begin{array}{l}0.29 \\
0.59 \\
0.47\end{array}$ & $\begin{array}{l}0.73 \\
1.62 \\
1.16\end{array}$ & $\begin{array}{l}1 \cdot 25 \\
2.77 \\
2.05\end{array}$ \\
\hline Speedframes & $\begin{array}{l}\text { Medium } \\
\text { Coarse } \\
\text { Total }\end{array}$ & $\begin{array}{l}0.21 \\
0.51 \\
0.38\end{array}$ & $\begin{array}{l}0.22 \\
0.64 \\
0.46\end{array}$ & $\begin{array}{l}0.54 \\
2.39 \\
1.52\end{array}$ & $\begin{array}{l}0.97 \\
3.54 \\
2.36\end{array}$ \\
\hline Combers & $\begin{array}{l}\text { Medium } \\
\text { Coarse } \\
\text { Total }\end{array}$ & $\begin{array}{l}0.25 \\
-\end{array}$ & $\begin{array}{l}0 \cdot 17 \\
-\end{array}$ & $\begin{array}{l}0 \cdot 35 \\
-\end{array}$ & $\begin{array}{l}0.77 \\
-\end{array}$ \\
\hline Ring frames & $\begin{array}{l}\text { Medium } \\
\text { Coarse } \\
\text { Total }\end{array}$ & $\overline{0.42}$ & $\begin{array}{c}\overrightarrow{0.49} \\
-\end{array}$ & $\begin{array}{c}\overrightarrow{1 \cdot 83} \\
-\end{array}$ & $\begin{array}{l}\overrightarrow{2 \cdot 74} \\
-\end{array}$ \\
\hline
\end{tabular}

subjective decrease in the severity of the symptoms of some operatives (Ministry of Labour, 1957, 1960, 1961). The improvement in the environment also appears to have reduced the risk of bronchitis which was prevalent earlier in the century (Home Office, 1932), as the Ministry of Pensions (1965) found that textile workers had a lower prevalence of bronchitis than expected on the basis of age and geographic location. Similarly, Lammers, Schilling, and Walford (1964) could find no significant difference in bronchitis prevalence between cardroom and spinning room operatives. As regards byssinosis, however, Wood and Roach (1964) found no evidence of a decreased prevalence of Monday tightness in the cardrooms of a small number of mills, and they found no consistent reduction in the atmospheric concentration of the finer dust fractions. The present study now shows that byssinosis was still prevalent in Lancashire mills in 1966; that total dust levels exceeded the TLV of $1 \mathrm{mg} / \mathrm{m}^{3}$ in the majority of processes and that bronchitis, in its different forms, was more prevalent in cotton operatives than in man-made fibre operatives.

As the operatives with byssinosis consisted of some with a long-standing history of symptoms and others who had only recently developed symptoms, a high overall prevalence, such as occurs in strippers and grinders and carders and undercarders, is not necessarily indicative of a high risk at the present time. Some of our observations, however, suggest that there is a continuing risk of byssinosis under recent working conditions. Symptoms were more prevalent in operatives working within the immediate vicinity of the cards, even with exposures of only 
short duration. The symptoms developed in coarse mills in less than five years and 76 out of 299 operatives developed symptoms during the two-year period from 1963 to 1965 . There is no indication that the results of the repeated questionnaire were biased by the method of presentation or by selfselection of the population. The same observers asked the same questions on both occasions and a similar proportion of the total population of each type of mill was represented, i.e., $45.7 \%$ for medium mills and $51.4 \%$ for coarse mills. The shorter latent period and the greater overall risk in coarse mills also correspond with the greater dust levels found in the cardroom processes. The fact that in medium and coarse mills similar proportions of byssinotics gave a change in grade of symptoms may be explained by the variable nature of the symptoms. Short-term changes in type of cotton and overall dustiness produce changes in subjective response, and symptoms are also influenced by extended absence from work such as the annual holiday. The questionnaire itself is likely to be unreliable in differentiating between grade I and II symptoms when the extension of tightness from Monday to Tuesday involves, by definition, a change of grade.

Some of the occupational groups consist of small numbers, but the prevalence of disease in these groups is of interest in relation to their cardroom location. The relatively high prevalence in ring spinners may be due to the fact that in previous studies, unlike this one, ring frames have been segregated from the cardroom. The high prevalence of byssinosis in wastemen in coarse mills reflects the relatively primitive methods of waste handling which were found in some parts of the industry.

A more precise interpretation of our findings on bronchitis will be attempted in a future paper when data concerning atmospheric pollution, grade of smoking habit, and details of dust exposure will also be presented. The difference in prevalence of bronchitis between the various groups of operatives is still sufficient to show that bronchitis of one type or another is increased in operatives with byssinosis, and consequently that exposure to raw cotton has been great enough in recent years either to produce or to be involved in the development of bronchitis. In non-byssinotics the most marked prevalence of bronchitis occurs in operatives who are exposed to cotton and who also smoke. The effect is seen mainly in bronchitis grade 1 . In byssinotics the increased prevalence in grade 1 bronchitis is also accompanied by an increased prevalence of grades 2 and 3 in both sexes, irrespective of smoking habit. Thus cotton workers appear to be exposed to a risk of bronchitis which increases with smoking and with the development of byssinosis. Our finding of a relationship between occupation and bronchitis prevalence is in general agreement with the findings of Pemberton (1968) and Lowe (1968) but a detailed comparison with these and other investigations (Ministry of Pensions, 1965; Lammers et al., 1964; Medical Research Council, 1966) is difficult due to differences in the concept of 'bronchitis'.

The effect of smoking habit on the prevalence of bronchitis in man-made fibre operatives is less consistent than might be expected and may be due to two factors. The first factor is our crude method of grading smoking habit and the second is that the great majority of the man-made fibre operatives had been exposed to cotton at some time in their working life; $59 \%$ of the total number had been exposed within five years of the start of this survey.

Some trends of the prevalence of respiratory symptoms may be explained by movement of labour in the industry, namely the significantly low prevalence of byssinosis in young operatives of less than 25 years of age and the decreasing prevalence in operatives with more than 30 years' of exposure. The latter has been noted in previous studies (Schilling et al., 1955).

The main findings from the 14 mills are sufficient to show that the dust control measures introduced during the period 1957-61, though at that time producing very great improvements in conditions, are not now controlling dust levels with the present methods of production. At the end of 1966 there was a continuing hazard of respiratory disease when cotton of low quality and high trash content was processed, and total dust loads in 12 of the 14 mills exceeded the recommended TLV of $1 \mathrm{mg} / \mathrm{m}^{3}$. Confirmation of the effect of present dust levels is given by the results of clinical assessment. A prevalence of byssinosis of $26.9 \%$ in the total population and a prevalence of $58.2 \%$ in card attendants is due only in part to conditions found before 1961 and indicates that present environmental control is meeting with only limited success.

Failure to control the disease can be attributed to a variety of reasons. The first is that approved dust extraction systems were only required to be fitted to the cards, whereas at least $50 \%$ of the cardroom population are employed on draw and speedframes. There is no doubt that a hazard exists in both these processes and that ringframes which process coarse yarn and which are also located in the cardroom are sufficiently hazardous to require some atmospheric control. A possible hazard in winding rooms, again where dust control is normally absent, has already been reported (Mekky et al., 1967). Another reason concerns the method of approval of the dust extraction systems and the failure to assess their performance in subsequent use. The systems were approved in terms of 'efficiency' by comparing the atmospheric dust level during carding with and without dust extraction (Ministry of Labour, 1957, 1960 and 1961), but these dust levels were not linked 
with a physiologically acceptable level of dust, such as the TLV suggested in 1960, though admittedly this was put forward after many installations had already been carried out. The need for checking the continuing efficiency of these measures after installation also was not fully realized.

Even though the recommended TLVrefers to total dust exposure, there is a strong case for measurement of the finer dust fractions, as will be referred to in a subsequent paper, since it is unlikely that anything other than the medium and respirable fractions can reach the lower respiratory passages. In the group of 14 mills, the proportion of the medium and respirable fractions varied from 32 to 15 and from 30 to $10 \%$ respectively. A similar variation occurred from process to process. It will thus be seen that the proportion of fly in the total dust is high and, if the figure for total dust is taken alone, it can conceal substantial variations of the other fractions. However, until the precise relationship between fine dust and risk of disease is known, it still seems necessary to adhere to the accepted criterion of total dust as an assessment of risk.

We are greatly indebted to the managements, workers, and welfare staffs of all the mills. Without their cooperation the survey could not have been made. The British Spinners' and Doublers' Association, the United Textile Factory Workers' Association, and the National Union of Textile and Allied Workers also gave us valuable support.

The planning of the survey was carried out by Professor R. S. F. Schilling and Dr J. C. Gilson and members of the Medical Research Council Pneumoconiosis Unit, in particular Dr. C. B. McKerrow, Mr. C. E. Rossiter, and Mr. G. Berry, and we are deeply grateful for their advice and assistance throughout, both on the medical and statistical sides, and in the evaluation of the results.

We wish also to thank Professor R. E. Lane, and his successor, Professor T. S. Scott, of the Department of Occupational Health of Manchester University for their help; Dr. T. A. Lloyd Davies, H.M. Senior Medical Inspector of Factories, and the Ministry of Labour (now the Department of Employment and Productivity) for their support; the Medical Research Council for a grant to one of us (MKBM), without which this study could not have been undertaken, and finally the technicians and other helpers who were involved in the day to day operation of the survey.

\section{References}

Berry, G. (1970). Parametric analysis of disease incidences in multiway tables. Biometrics, 26. In press.

Bouhuys, A., Heaphy, L. J., Schilling, R. S. F., and Belborn, J. W. (1968). Byssinosis in the United States. New Engl. J. Med., 278, 509-510.

Home Office (1932). Report of the Departmental Committee on Dust in Cardrooms in the Cotton Industry. H.M.S.O., London.

Lammers, B., Schilling, R. S. F., and Walford, J. (1964). A study of byssinosis, chronic respiratory symptoms, and ventilatory capacity in English and Dutch cotton workers, with special reference to atmospheric pollution. Brit. J. industr. Med., 21, 124-134.

Lowe, C. R. (1968). Chronic bronchitis and occupation. Proc. roy. Soc. Med., 61, 98-102.

McKerrow, C. B., McDermott, M., Gilson, J. C., and Schilling, R. S. F. (1958). Respiratory function during the day in cotton workers: A study in byssinosis. Brit. J. industr. Med., 14, 75-83.

Medical Research Council (1960). Standardised questionnaire on respiratory symptoms. Brit. med. J., 2, 1665.

(1966). Chronic bronchitis and occupation. Brit. med. J., 1, 101-102.

Mekky, S., Roach, S. A., and Schilling, R. S. F. (1967). Byssinosis among winders in the cotton industry. Brit. J. industr. Med., 24, 123-132.

Ministry of Labour. Third (1957), Fourth (1960), and Final (1961). Dust in Card Rooms. Reports of the Joint Advisory Committee of the Cotton Industry. H.M.S.O., London.

Ministry of Pensions and National Insurance (1965). Report on an Enquiry into the Incidence of Incapacity for Work, Part II, No. 76-17-2. H.M.S.O., London.

Pemberton, J. (1968). Occupational factors in chronic bronchitis. Proc. roy. Soc. Med., 61, 95-98.

Prausnitz, C. (1936). Investigation on Respiratory Dust Disease in Operatives in the Cotton Industry. Spec. Rep. Ser. med. Res. Coun. (Lond.) No. 212.

Roach, S. A., and Schilling, R. S. F. (1960). A clinical and environmental study of byssinosis in the Lancashire cotton industry. Brit. J. industr. Med., 17, 1-9.

Schilling, R. S. F., Hughes, J. P. W., Dingwall-Fordyce, I., and Gilson, J. C. (1955). An epidemiological study of byssinosis among Lancashire cotton workers. Brit. J. industr. Med., 12, 217-227.

Wood, C. H., and Roach, S. A. (1964). Dust in card rooms: A continuing problem in the cotton spinning industry. Brit. J. industr. Med., 21, 180-186.

Wright, B. M. (1954). A size-selecting sampler for airborne dust. Erit. J. industr. Med., 11, 284-288.

Received for publication July 15, 1969. 